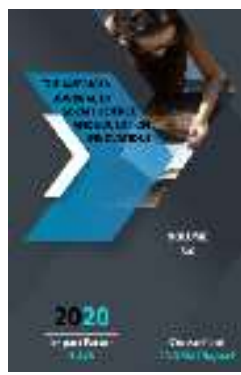

\title{
A Stamp Printed By The National Liberation Movement
}

\author{
Alijon Safarov \\ Senior Lecturer, Journalism And Mass Communications University Of Uzbekistan
}

Journal Website:

http://usajournalshub.c

om/index,php/tajssei

Copyright: Original

content from this work

may be used under the

terms of the creative

commons attributes

4.0 licence.

\section{ABSTRACT}

The national liberation movement against the establishment of the Soviet system in Uzbekistan was insulted by the great state chauvinists under the false name of "repression". This article explains what lies behind this tyrannical policy, the essence of the struggle of our ancestors for freedom and liberty through historical facts and evidence.

\section{KEYWORDS}

Red Army; Krasnaya Zvezda; Turkiston; Turkfront; ideology; tyrant; "oppressor"; council; revolution.

\section{INTRODUCTION}

Before touching on this topic, two important facts came to my mind. The first is the autonomy of Turkestan. "Independence" that was crushed by the Bolsheviks and lasted for 72 days. Centuries-old dreams and aspirations, founded on November 28, 1917 in Kokand and completed on February 22, 1918 by the Turkestan Commissariat and groups of the Soviet army sent to it from the center. The second was the Declaration of Independence, adopted on June 20, 1990. In this important document, which is 30 years old, the bloodsoaked autonomy of Turkestan, the national liberation struggle buried in the wounded page of our history, had a real right. The ancestors who sacrificed their lives for the only line of paragraph 8 of the Declaration, "The Uzbek SSR determines its own path of development, its own name and establishes its own state symbols (coat of arms, flag, anthem)." It is this 
dream, the right of aspirations, that we have found necessary to refer to the history of the struggle for national liberation.

The stamp of the national liberation movement in Uzbekistan has not left our foreheads for many years. False history, full of insults such as " invader " and " invader ", is read and raised not by one, but by several generations. History has not kept this arrogance, the falsity of the Soviet ideology for a long time. The truth came out. It is our duty to restore the historical memory, to explain with concrete examples that those who defended their country, freedom, religion were heroes of the nation, not oppressors. It is important to further strengthen our independence, learn from the past, and be vigilant and vigilant. In this article, we would like to draw your attention to the topic with historical facts and evidence.

\section{MAIN PART}

Where does the term "invader" come from? Let us first answer this question. From the explanatory dictionary of the Uzbek language we look at the "passport" of the word, that is, "identity". "Repression is an act based on violence and aggression; aggression, theft, banditry. "Bosmachilik" is the official name given to the armed movement of the general public in Turkestan against the Red Army in 1918-1925 by the great state chauvinists during the Soviet era. [1]

So, the Soviet ideologues gave such an official name to the movement of our ancestors for freedom and liberty. We will turn to the evidence to further supplement this information. The book "Uzbekistan in the period of Soviet colonialism" states that the word " invader " does not appear in archival documents from mid-1918 to 1919. [6] In other words, the words "robber", "bandit", "gang" were used for those who fought for national liberation in Fergana. We read in the book: "From the middle of 1919, the term" invader "began to be used in the Soviet periodical press, and later in some official documents. The terms "oppressor" and "oppressor" were coined by the great statesmen-chauvinists to denigrate the essence of the national liberation movement, to denounce the bloody struggle of our ancestors against Bolshevik rule, and were unjustifiably equated with the words "banditry" and "robbery." The ideologues of communism and their articles often called the national liberation movement up to 1917 by this term".[6]

There is a basis for this view put forward by our historians. The ideological "army" of the Soviets, the military press, was invaluable in this. Look at his strength, he did what a toothand-nail army could not do. The sacred notion of freedom without bloodshed pierced the "dagger" of the word into the "throat" of emotion. Though our tongues wept for blood, our tongues joined the executioners and uttered this word. Probably a factor as to why they're doing so poorly.

Historian Nodirbek Khamaev writes: "During the armed struggle against the Soviet regime in Turkestan, the number of such newspapers (military publications, commentary) exceeded 20. Examining the current issues of the newspapers, we came to the conclusion that their main task was to establish the Red Army in Turkestan, to provide ideological assistance in the military and moral training of soldiers in the fight against the "invaders" and to carry out propaganda work in the Red Army". [3]

Like a mushroom that blossomed after the rain, one after another appeared in our 
country, raising the flag high in the fight against "oppression". We would call more than 20 publications the ideological army of the Soviets. These include Krasnoarmeets, Krasny Front, Gornist, Borets kommunizm, Krasnoarmeyskaya Newspaper, Nabat Revolution, Ejenedelnik Politrabotnika, and Krasnaya Zvezda. The military press went to the forefront of the armed forces to suppress the struggle for national liberation, to erase this reality from our historical memory.

\section{RESULTS AND DISCUSSIONS}

Turkfront's Krasnaya Zvezda newspaper has played an important role in the struggle against national liberation, in the propaganda of the tyrants against the eradication of "oppression" and in the manipulation of public opinion. In the department of rare publications and manuals of the National Library of Uzbekistan named after A.Navoi, in the fund number G-40 are stored the pages of the newspaper "Krasnaya Zvezda" published in 1922-1923.

This is evidenced by the fact that in the 1922 and 1923 issues of the newspaper, articles and reports were regularly published in such sections as "We will put an end to tyranny", "Against tyranny", "Fight against tyranny". Did our forefathers, who did not know bravery, kind, greed, and thought that the battle would take place only in the open, know how powerful a weapon it would be if information was directed towards a selfish, evil goal? Did he realize that the cunning enemy was stabbing him in the back? It is on this issue that our ancestors were ignorant, in my case. The word poisoned by the enemy showed the power of information. He was paralyzed.

In the December 18, 1923 issue of the "Krasnaya Zvezda" newspaper, an article was published under the heading "Front Conference of Military Correspondents." This is a report by Shaposhnikov, a member of the Revolutionary Military Council of the Turkfront and head of the political department of the front, entitled "The Military-Political Situation of the Turkfront and the Red Army Press". In the introductory part of the report, the editor commented: "In his report, Comrade Shaposhnikov described the situation with the repression movement in Turkestan, the main tasks in the fight against the Bukhara oppressors, and then the international situation, and the role of the Red Army newspaper and military correspondents". [4]

What does this indicate? As you can see, a senior ideological official of the Turkfront Military Council instructed reporters on how to write about "repression." Not only editorial staff, but also public correspondents from the Red Army were involved in such conferences.

At the conference, the official will first focus on the problem of "repression" and then on international issues. However, the struggle to divide the world was intensifying, and the threat of important "players" in the political ariea was a period of concern and danger for the Soviets. The international issue was in turmoil. In addition, the appetite of the genius and his henchmen was aroused, and he was anxious to carry out a "world revolution" and spread the virus around the world. Despite all the problems, why did Shaposhnikov focus on the headache of "printing" as a topical issue, telling military reporters?

The question is relevant. If we answer based on facts and logic, there was fear and fear in the councils. The fear of losing the land, which has innumerable underground and surface resources, ready-made "slaves" who will 
supply raw materials. It is the fear that if the whole nation joins the national liberation movement, it will not be stopped. Fear of awakening in the blood of the ancient courage of the Turkish people. This fear had to be used to "kill" the panic, to punish, to deceive, to conspire, to use any means of oppression. Otherwise ... Yesterday could have been returned. I am referring to the uprisings and uprisings against Tsarist Russia by the local population until the end of the nineteenth century and the October coup. The Soviets could not have been unaware of this. The reality had not yet "cooled down."

We found the way to the reality through the book "Turkestan - Colony" by Soviet historian Peter Galuzo, published in 1929. [2] The table in the book shows that between 1899 and 1917, there were 4,922 revolts against the Tsarist government in Fergana, Samarkand, Hazarbay, Syrdarya, and Yettisuv regions. Note: About 270 revolts per year. It means a daily revolt, protest, resistance, struggle against the tyranny of the tyrants almost every day. For example, if we look at the data for 1917 alone, we see that the people revolted 324 times in Fergana, 171 times in the Caspian Sea, 47 times in Samarkand, and 5 times in Yettisuv - a total of 547 times. That is why the Soviets used both weapons and ideological force to suppress the national liberation movement!

That is why the military press has been burdened. Shaposhnikov's remarks to reporters are as follows: "At the moment, your most important task is to shed light on the political shift and change we are making with the local population and the Red Army in the struggle on the printing front". [4]

This article, published in "Krasnaya Zvezda", shows that the tasks set out in the resolution of the Conference of Military Correspondents on the Front were not in vain the Soviet government paid special attention to public military correspondents (propagandists) and propagandists. The goal was to get what he could not get with a knife, what he could not conquer with a pen, a word, that is, the power of propaganda.

The fact that even some Soviet ideologues have acknowledged that the national liberation movement is not looting, robbery, or oppression shows that the insidious policy of the dictatorial regime is at the root of this stigma attached to our foreheads.

In his book "Colonial Revolution" (Experience of Turkestan) the revolutionary Georgiy Safarov, a member of the Turkburo, described the "repression" movement as a struggle for national liberation, the suppression of "Kokand autonomy" and, consequently, colonialism. origin, he says [5] On the other hand, it is linked to the economic crisis, famine, and the disruption of the cotton-growing process in Fergana. That is, it explains the deterioration of the financial situation of the rich, the fact that laborers, quartermasters and workers are left without wages. The dictatorial policy that continued even after the Tsarist colonization had devastated agriculture. Are you paying attention? All the reasons given show the essence of the nation's struggle. What was to be done against so much oppression? Fewer people are labeled "printers".

According to the book "Uzbekistan during the Soviet colonial period", in the early 1920 s M. Frunze sent an urgent letter to the commander of the Fergana front. It reads: "Fergana, the pearl of Turkestan, has been a bloody battlefield for more than two years. . In the nationalization of production, not only the 
property of the bourgeoisie, but also of the middle peasants was taken away ... The Red Army units that acted here, some leaders who defended the revolution, understood the working people as a means of oppression. This movement, called the printing press, came into being on this basis. The invaders are not ordinary pirates. Then it would be possible to destroy them quickly". [7] The text of this hasty letter is taken from the Russian State Military Archive (RGVA, f.110, op.3, d. 234, I. 4-5).

Fergana scholar Nodirbek Khamayev cites the author S. Shur in his scientific article "Armed action against the Soviet regime and the military press in Uzbekistan." He published an article in the July 4, 1920 issue of the Red Army newspaper Proletarskiy Mysl, entitled Korni Basmachestvo, and in the third issue of Krasnaya Kazarma, entitled Borba za krasny Turkestan. In the articles, the author writes that the "repression" movement in Fergana was the result of the abuse of power by some officials of the Soviet government.

\section{CONCLUSION}

It is also clear from the examples given that this struggle was a people's movement against the tyranny of the dictatorial regime. False accusations of robbery, robbery, and aggression were nothing more than a humiliation of his political position.

We pondered around the two questions above. That is, we tried to analyze how skillfully the military press was used to suppress the national liberation movement and what was in fact the essence of this struggle. At the end of the article, it would be appropriate to clarify the question of who the publisher was.

This is evidenced by Madaminbek's letter dated March 11, 1919 to the commander of the
Fergana front M. Safonov. About this letter stored in the State Archives of Russia ( $f .28113$, op.1, d.1, I.1; f.149. Op.1, d.51, I.53.) In the book "Uzbekistan in the period of Soviet colonialism" mentioned. [7] So what do you think Madaminbek wrote? Let's look at an important part of the letter together: "In Turkestan, I repeat, you have nothing to do, and here you only make enemies by force ... You announced the formation of a federation, you declared the right of the people to selfdetermination, so why don't you give them to us? Or is it just because we are Muslims? Let us live as we please, let us follow the slogans you have proclaimed, let us choose the way we want to govern, because we Muslims are the majority. But don't use violence ..."

The huge army, armed with the label "Bosmachi" and a fingernail, went to war with such harsh words as "do not use violence", "return the right to self-determination", "give us the right to rule as we wish", "do not discriminate because we are Muslims". It was the oppression of the people against oppression.

In the letter, Korboshi wrote that he had become a gang of invaders and commanders of the Red Army.

Here is a historical fact for you. What if a single squadron commander of the Soviet plundered so many ordinary people?! Isn't that a piracy?! What kind of equality, what kind of "isms" can those who plunder the beds and blankets of the suffering people, who are barely breathing from hunger and helplessness, talk about? In my opinion, the word "Bosmachi" is ashamed of them. Many such examples can still be found in "old" history. 
The national liberation movement in Turkestan is on the one hand, and the political, ideological and armed struggle is on the other. The struggle for justice, freedom, and justice is on the one hand, and the bloody methods based on savagery, violence, and oppression are on the other.

Who was the oppressor and who defended his freedom, honor and dignity?! The scales had to be broken by this, in fact.

We must learn the right lessons from these truths buried in the deep, wounded of history, call those who fought for national liberation by their own names, and appreciate the independence we have been granted today. The waking world seems to be telling us the same.

\section{REFERENCES}

1. Annotated Dictionary of the Uzbek Language, p. 321, www.ziyouz.com library.

2. Galuzo P.G. "Turkestan - colony", Moscow, 1929., p.135.

3. Khamaev N. "Armed action against the Soviet power and military press in Uzbekistan", "Look to the past" magazine, 2019., issue 10, p. 71.

4. “Krasnaya Zvezda”, December 18, 1923, No. 280 (667).

5. Safarov G. "Colonial revolution (Opyt Turkestana)", Gosudarstvennoe izdatelstvo, 1921., p. 90.

6. "Uzbekistan in the period of Soviet colonialism", the second book of the new history of Uzbekistan, "Sharq" publishing house, 2000., p. 84, https://ziyouz.uz/durdona-

toplamlar/uzbekistonning-yangi-tarihi.

7. "Uzbekistan in the period of Soviet colonialism", the second book of the new history of Uzbekistan, "Sharq" publishing house, 2000, p.90-91, https://ziyouz.uz/durdonatoplamlar/uzbekistonning-yangi-tarihi.

8. Nargizakhon Abduqahharovna Sharipova. (2020). Involvement of school teachers in Uzbekistan in agricultural work. Journal of Central Asian Social Studies, 1(01), 45-55. https://doi.org/10.37547/jcass/volume01issu e01-a5 